\title{
Assessment of pollution caused by tannery-waste and its impact on aquatic bacterial community in Hajaribag, Dhaka
}

\author{
Mahbubul Hasan Siddiqee, ${ }^{1+}$ Md. Saiful Islam ${ }^{2}$ and M. Majibur Rahman ${ }^{3}$ \\ ${ }^{1}$ Microbiology Program, Department of Mathematics and Natural Sciences, BRAC University, Dhaka-1212, Bangladesh; \\ ${ }^{2}$ Department of Microbiology, Stamford University Bangladesh, Dhaka-1217, Bangladesh; ${ }^{3}$ Department of Microbiology, University \\ of Dhaka, Dhaka-1000, Bangladesh
}

Received 10 July 2012/Accepted 01 October 2012

\begin{abstract}
The leather industries of Hajaribag area, Dhaka city, produce hundreds of metric tons of inorganic and organic wastes which pollute the adjacent water bodies including the river Buriganga. In the present study, a total of 18 water samples from 6 different points along the effluent distribution route were examined. Along with the dissolved oxygen concentration (DO), acidity (pH), conductivity, and concentration of total dissolved solute (TDS), concentration of the samples were measured followed by the enumeration of total heterotrophic bacteria. Pure cultures of bacterial isolates were obtained after a brief enrichment and the isolates were biochemically identified up to genus level. The physicochemical test readings showed significant fluctuations in different points indicating radically heterogeneous conditions throughout the distribution system. The total count varied from $1.2 \times 10^{2}$ to $6.3 \times 10^{3} \mathrm{cfu} / \mathrm{ml}$. Different bacterial genera including Alcaligenes spp., Bacillus spp., Corynebacterium spp., Escherichia spp., Micrococcus spp., Pseudomonas spp., Shigella spp., Staphylococcus spp. and Streptococcus spp. were isolated from the collected samples. The bacterial community was found to be diversified where the concentration of tannery waste was less; thereby it was assumed that the tannery waste might affect the aquatic bacterial community both quantitatively and qualitatively.
\end{abstract}

Key words: Tannery waste; pollution; bacterial community

Today natural ecosystems have very little to do with the newer kinds of pollution as its self-purification systems are put to test by ever increasing human population and also by industrialization. Tanning industries are one of the major manufacturing processes which are responsible for tremendous pollution of water resources (1-3). In these industries, animal hides are transformed into leather through many complex stages, consuming high quantities of water and using large amounts of chemicals such as lime, sodium sulfide, ammonium sulfate, sodium chloride, bactericides, vegetable tannins, and chrome salts (4). Tannery wastewaters are mainly characterized by high salinity, high organic loading, and specific pollutants such as sulfide and chromium $(5,6)$.

The initial processing of raw hides release organic waste, and sulfide contents in the environment. The tanning process uses very high concentration of inorganic salts of chloride, ammonia, chromium, and sulfate, which may responsible to cause pollution (7). Presence of organic matter in the environment showing Chemical Oxygen Demand (COD) or Biological Oxygen Demand (BOD), is a matter of concern in

${ }^{\ddagger}$ Corresponding Author: Mailing address. Mahbubul Hasan Siddiqee, Microbiology Program, Department of MNS, BRAC University, 66 Mohakhali, Dhaka, Bangladesh; E-mail: msiddiqee@ bracu.ac.bd. governing the after-effect of these pollutants. Their disposal to water bodies might cause depletion of oxygen leading to harmful effects on living entities $(8,9)$. On the other hand, inorganic pollutants of chromium-rich tannery wastes to disposal sites cause significant changes to the physicochemical properties of that environment (10-12).

Substantial number of reports showed the effect of tannery wastes on water bodies. It is likely that changes in the physicochemical properties of water might directly or indirectly influence microbial populations and their activities. Such influences can be measured through monitoring the qualitative and quantitative changes in physicochemical properties of different locations and respective microbial community structure.

Moreover, information on the effect of contaminants on water microbial community is considered critical to the development of any sustainable bioremediation strategies for cleanup of tannery waste contaminated sites. For this reason, we investigated the impact of tannery-wastes on the physicochemical properties of the nearby water bodies at the Hajaribag site, and the associated effect on changing the population structure and microbial load of the water.

\section{MATERIALS AND METHODS}

Sample site and sampling. Six different locations (Table 1) from nearby locality
of Hazaribagh tannery industries (Fig. 1) of Dhaka city and the flow path of the disposed effluent were selected for the collection of samples and 3 samples were 


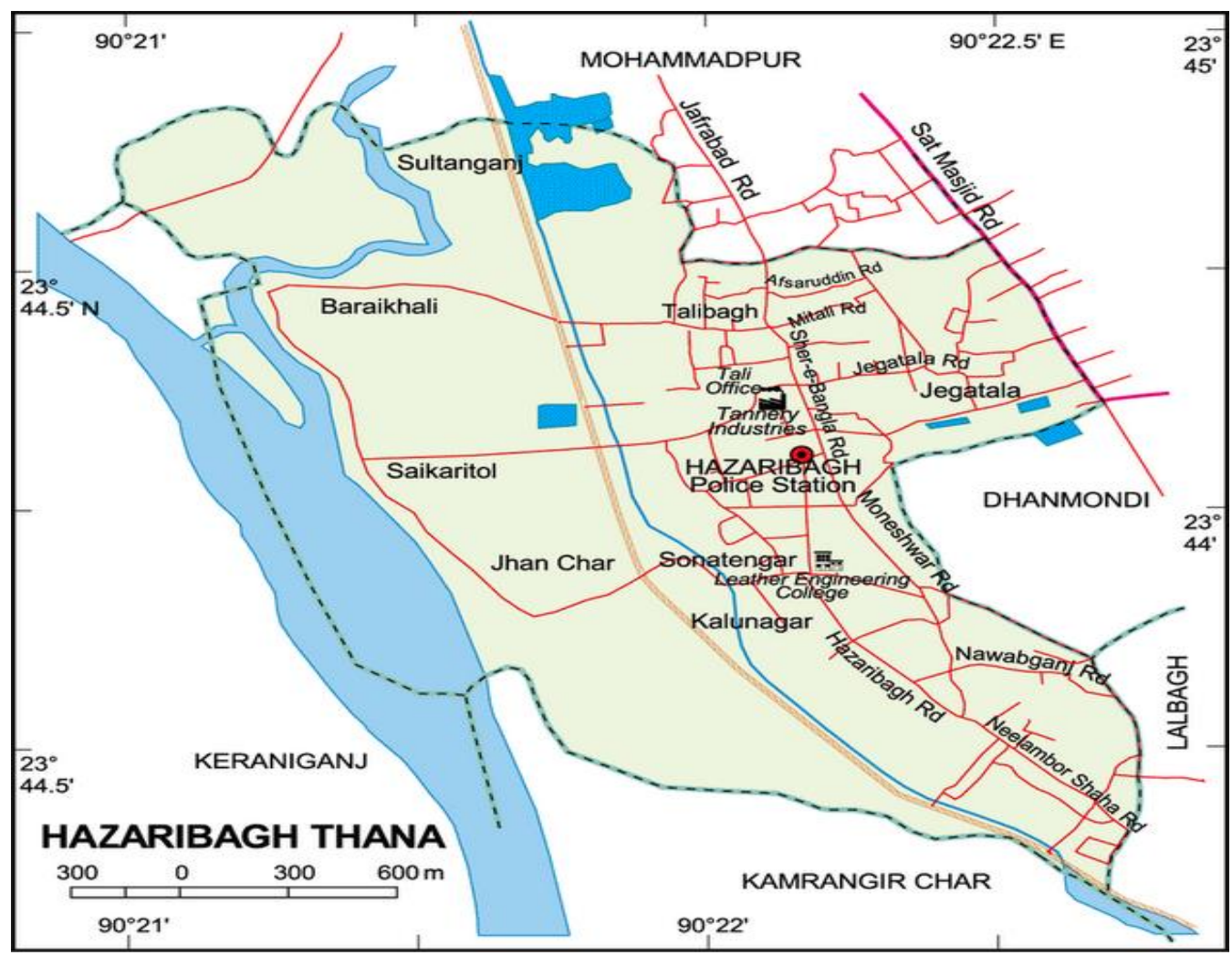

FIG. 1. Map of Hazaribagh. The study area is indicated by the red/dotted circle.

TABLE 1. Description of sampling sites.

\begin{tabular}{ccc}
\hline $\begin{array}{c}\text { Serial } \\
\text { no. }\end{array}$ & Sampling site & Code \\
\hline 1 & Tannery floor & TF \\
2 & Retention tank for mixing salt with raw & RT \\
3 & Tannery-exit for effluent & EP \\
4 & Between tannery-exit and sluice slum & ES \\
5 & Water logged sites in the sluice slums & SS \\
6 & Burigonga River & RV \\
\hline
\end{tabular}

collected from each location. A total of $250 \mathrm{ml}$ of water sample was collected aseptically from each point in sterile plastic bottle.

Measurement of physicochemical parameters. The physicochemical parameters were examined in the laboratory just after the samples had become available. Probe based detection of $\mathrm{pH}$, dissolve oxygen (DO), conductivity and total dissolve solid (TDS) were performed.

Inoculation of samples. All samples $(6 \times 3=18)$ were divided into 2 sets of aliquots. One set was selected for the direct measurement of total heterotrophic plate count and the other set was subjected to enrichment. Both the enriched and non-enriched sets of samples were serially diluted up to 100 fold using physiological saline and all the dilutions were used for the assessment of bacterial composition in qualitative and quantitative manner, respectively.

Enrichment of the samples was done with peptone water at room temperature in test tubes for 3 hours. Three milliliter from each water sample was mixed with previously prepared and autoclaved $3 \mathrm{ml} 2 \mathrm{X}$ peptone water. This enrichment was done to revive the vitiated organisms. Nutrient agar (NA) and peptone agar (PA) were used for the enumeration and isolation of aerobic heterotrophic bacteria by using spread plate technique and incubated at $37{ }^{\circ} \mathrm{C}$ as described by Sharp and Lyles in 1969 (14)

Identification of microorganisms. Identification of bacterial isolates was carried out according to Bergey's Mannual $(15,16)$. For further confirmation, several biochemical tests were performed according to the Manual of Methods for General Bacteriology by American Society for Microbiology (17) to identify bacteria.

\section{RESULTS}

Physicochemical parameters. The trend of change in the physicochemical parameters (Fig. 2) which is depicted taking the average of the three samples collected for each of the parameters. DO was found in its highest level in the tannery floor to be $5.9 \mathrm{mg} / \mathrm{L}$ before declining drastically in mixing tank to $0.3 \mathrm{mg} / \mathrm{L}$. It then increased again to 4.8 $\mathrm{mg} / \mathrm{L}$ at exit point before fluctuating further a little in later sampling sites. TDS showed its peak value of $5.1 \mathrm{mg} / \mathrm{L}$ at mixing tank and continued to decrease gradually afterwards. $\mathrm{pH}$ was somewhat neutral in the beginning and was highly alkaline in the mixing tank. Then it reverted to slight acidity in the rest of the points. Conductivity was found in its highest degree (1966 $\mu \mathrm{S} / \mathrm{cm})$ in the mixing tank and then decreased dramatically to $3.1 \mu \mathrm{S} / \mathrm{cm}$ in the exit point. In between exit point and the sluice slum conductivity increased to $8.2 \mu \mathrm{S} / \mathrm{cm}$ before decreasing gradually in the sluice-slum and in Buriganga.

Determination of Microbiological Quality. It was obvious that the range of bacteria (Table 2) 


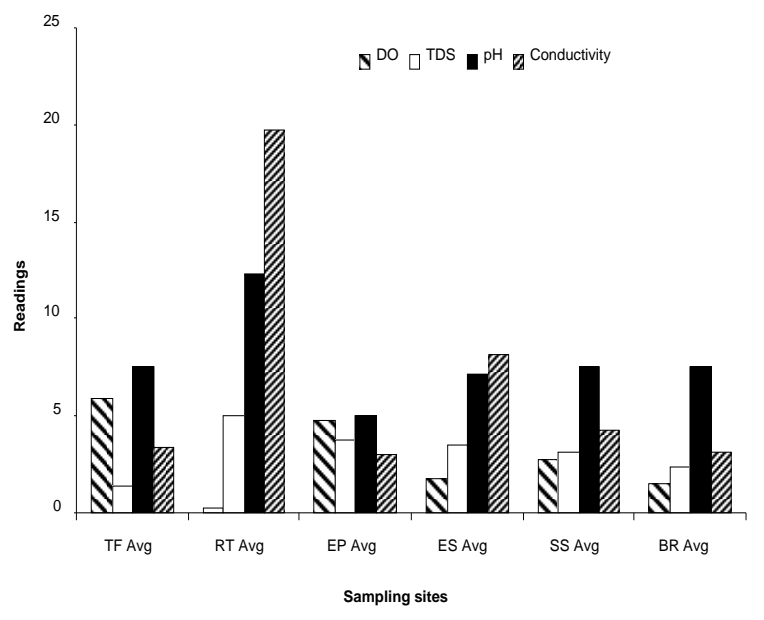

DO $=$ Dissolve oxygen $;$ TDS $=$ Total dissolve solid $;$ Avg $=$ Average $\mathrm{TF}=$ Tannary floor; $\mathrm{RT}=$ Retention tank; $\mathrm{EP}=$ Exit point; $\mathrm{ES}=\mathrm{In}$ between exit point and sluice slum; $\mathrm{SS}=$ Sluice slum; $\mathrm{BR}=$ Buriganga River

FIG. 2. Trend of changes in physicochemical properties along the sampling sites. TDS and conductivity shows somewhat similar pattern of fluctuation. $\mathrm{pH}$ is seen to be roughly uniform except sharp rise in the retention tank and abrupt fall in the exit point. Dissolved oxygen (DO) shows highest level of fluctuation depending on the type of samples.

varied from point to point. The tannery floor contained highest degree of diversity with eleven bacterial species. This diversity decreased slightly in the retention tank with 7 different genera and in the exit point with three variants only. The trend changed as the waste stream approached away from the tannery and contained 6 genera in location between exit and sluice slum. Ten genera were found in the logged water body of sluice-slum and 8 in the river Buriganga. The average of the HPC from three samples for each location has been shown (Fig. 3). Microbial load of tannery floor ranged between $4.3 \times 10^{3}-6.3 \times 10^{3} \mathrm{cfu} / \mathrm{ml}$. This diversity fell inside the tank where the hides were kept with high concentration of various inorganic salts. However, $1.2 \times 10^{2}-1.6 \times 10^{2} \mathrm{cfu} / \mathrm{ml}$ bacteria were found which possibly indicates higher tolerance to elevated salt concentration. The load then increased again to $1.2 \times 10^{3}$ $2.5 \times 10^{3} \mathrm{cfu} / \mathrm{ml}$ at exit point before decreasing to $8.4 \times 10^{2}$ $1.3 \times 10^{3} \mathrm{cfu} / \mathrm{ml}$ in the location between exit point and the sluice slum. It then further decreased to $4.6 \times 10^{2}-4.9 \times 10^{2}$ $\mathrm{cfu} / \mathrm{ml}$ in the sluice slum before a slight increase to $9.6 \times 10^{2}-1.7 \times 10^{3} \mathrm{cfu} / \mathrm{ml}$ in the Buriganga river.

The degree of correlation between the quantitative and qualitative variations along the waste distribution system (Fig. 3) was also calculated. Sites that showed higher variation were associated with higher counts and sites with less variation were associated with lower counts. However, two sites, namely, exit point and sluice-slum did not conform to this trend. In exit point the quantitative count $\left(1.2 \times 0^{3}-2.5 \times 10^{3} \mathrm{cfu} / \mathrm{ml}\right)$ was high enough in contrast to only 3 genera in that location. However, sluice-slum showed the opposite trend of having ten variants to account for a surprisingly low count.

\section{DISCUSSION}

The chemical nature of the pollution caused by tannery effluent has been well characterized by the previous researchers. But, the assessment of their impact from the microbiological point of view is still not addressed

TABLE 2. Bacterial spectrum at different sampling points that shows significant variation from site to site referring much to their adaptability to the prevailing conditions. Not all bacteria are found everywhere.

\begin{tabular}{|c|c|c|c|c|c|c|}
\hline Sample & Burigonga River & Sluice slum & $\begin{array}{l}\text { Between exit and } \\
\text { sluice slum }\end{array}$ & Exit Point & Retention Tank & Tannery Floor \\
\hline 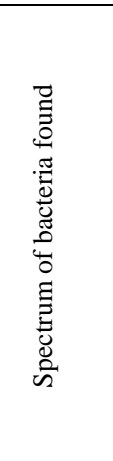 & $\begin{array}{l}\text { Staphylococcus } \\
\text { aureus } \\
\text { Streptococcus spp. } \\
\text { Bacillus spp. } \\
\text { Streptococcus lactis } \\
\text { Micrrococcus luteus } \\
\text { Micrrococcus spp. } \\
\text { Bacillus cereus } \\
\text { Pseudomonas spp. } \\
\text { Escherichia coli }\end{array}$ & $\begin{array}{l}\text { Micrrococcus luteus } \\
\text { Staphylococcus spp. } \\
\text { Streptococcus lactis } \\
\text { Corynebacterium } \\
\text { xerosis } \\
\text { Alcaligenes faecalis } \\
\text { Corynebacterium spp. } \\
\text { Bacillus spp. } \\
\text { Shigella } \text { spp. } \\
\text { Staphylococcus } \\
\text { aureus } \\
\text { Shigella dysenteriae }\end{array}$ & $\begin{array}{l}\text { Micrrococcus luteus } \\
\text { Psuedomonas } \\
\text { aeruginosa } \\
\text { Corynebacterium } \\
\text { xerosis } \\
\text { Staphylococcus spp. } \\
\text { Streptococcus lactis } \\
\text { Shigella dysenteriae }\end{array}$ & $\begin{array}{l}\text { Shigella } \\
\text { dysenteriae } \\
\text { Klebsiella } \\
\text { spp. } \\
\text { Shigella } \\
\text { spp. }\end{array}$ & $\begin{array}{l}\text { Bacillus spp. } \\
\text { Psuedomonas aeruginosa } \\
\text { Corynebacterium xerosis } \\
\text { Micrrococcus luteus } \\
\text { Bacillus cereus } \\
\text { Streptococcus } \\
\text { Staphylococcus aureus }\end{array}$ & $\begin{array}{l}\text { Escherichia coli } \\
\text { Alcaligenes faecalis } \\
\text { Streptococcus lactis } \\
\text { Micrrococcus luteus } \\
\text { Psuedomonas } \\
\text { aeruginosa } \\
\text { Staphylococcus } \\
\text { aureus } \\
\text { Corynebacterium } \\
\text { xerosis } \\
\text { Pseudomonas spp. } \\
\text { Streptococcus spp. } \\
\text { Bacillus spp. } \\
\text { Shigella dysenteriae }\end{array}$ \\
\hline $\begin{array}{l}\text { No. of } \\
\text { variants } \\
\text { (genus) }\end{array}$ & 8 & 10 & 6 & 3 & 7 & 11 \\
\hline
\end{tabular}




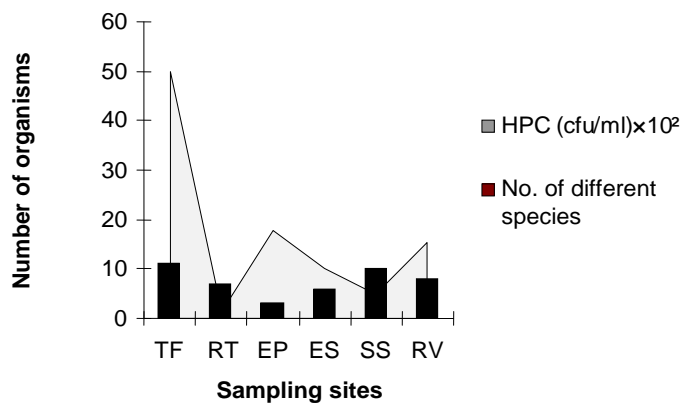

$\mathrm{HPC}=$ Heterotrophic plate count; $\mathrm{TF}=$ Tannary floor; $\mathrm{RT}=$ Retention tank; $\mathrm{EP}=$ Exit point; $\mathrm{ES}=\mathrm{In}$ between exit point and sluice slum; SS = Sluice slum; BR = Buriganga River

FIG 3: Correlation of changes in HPC and number of variants along the sampling locations indicating association of higher count with greater diversity of bacteria. It is obvious that the tannery floor was the most favorable site for thriving microbes whereas retention tank was the least favorable site for microbial growth. Other sites were found to be moderately supporting growth with notable exception of logged water body of sluice slum where low HPC count was found.

properly. In this study, an attempt was made to concentrate on this point and to unveil the big picture by assessing the relevant parameters to correlate the nature and causes of pollution.

When qualitative assessment of the range of aerobic heterotrophic bacteria was considered, the range of bacteria was found to be affected by the horizontal movement of the waste stream (Table 2). The highest number of bacterial genera associated with tanneryfloor was likely because of continuous supplementation by inflow of fresh hides containing all sorts of organic matters as well as least amount of any inhibitory elements. Even if the toxic elements were present in those locations, their inhibitory effect was superseded by the supplementary effect of the organic support. This observation was very significant and indicated that there was something in the tannery effluent which was not present in the tannery floor. A closer look revealed that this inhibition was contributed by the heavy metal salts used in tannery industry which might have toxic effect. Lower concentration of the heavy metals is usually associated with longer distance from the tannery cluster due to dilution effect (18). So, the inhibitory action weaned gradually and this was indicated by further increase in the diversity of microbial community.

The diversity of physicochemical conditions and difference in the level of limiting factors to microbial growth could most likely be responsible for the quantitative and qualitative variation (19). This hypothesis got ground when the readings of physicochemical parameters were analyzed (Fig. 2).
Higher HPC as well as higher variation was observed (Fig. 3) where the parameters were found within the limit supportive to growth of organisms. On the other hand, where conditions were highly unfavorable, e.g. in retention tank, the count and the variation of organisms were strikingly less.

Same bacteria were not found everywhere. It depended on their source to be introduced in an environment as well as the relevant parameters for growth and survival in that environment (18). It was clear from the data of physicochemical parameters of different samples that not all situations throughout the flow path were suitable for growth or even survival for all type of bacteria. In the end, with the more clear insight of microbiological interactions with tannery-waste our research can be proved important for designing more efficient processing to make it environment-friendly and cost effective.

\section{REFERENCES}

1. Dereje, T. 2006. Biological Sulfide Removal from Tannery Wastewater using anoxic-oxic bioprocesses. M.Sc. Thesis, Addis Ababa University, Ethiopia.

2. Lelissa, S. 2007. Developing water quality index for tannery wastewaters:A tool for environmental pollution monitoring. M.Sc thesis.Addis ababa university, Ethiopia.

3. Seyoum, L., A. Fassil, and D. Gunnel. 2003. Characterization of tannery wastewater and assessment of downstream pollution profiles along Modjo River in Ethiopia. Ethiop. J. Biol. Sci. 2 (2): 157-168.

4. Cooman, K., et al. 2003. Tannery wastewater characterization and toxicity effects on Daphnia spp. environmental toxicology 18 (1): 45-51.

5. Tunay, O., D. Orhon, and I. Kabdasli. 1994. Pretreatment requirements for leather tanning industry wastewaters. Water Sci Tech. 29 (9): 121-128.

6. Song, Z., C. J. Williams, and R. J. Edyvean. 2000. Sedimentation of tannery wastewater. Water Res. 34: 2171-2176.

7. Mene'ndez C. and M. Di'az. 1998. Tannery wastewater treatment (in Spanish). Tecnologi'a de agua 183: 27-32.

8. Fantahun, W. 2005. Evaluation of nitrogen removal rates from abattoir wastewater in a pilot predenitrification-nitrification activated sludge wastewater treatment plant. M.Sc. Thesis, Addis Ababa University, Ethiopia.

9. Hoshino, T., et al. 2005. Molocular analysis of microbial population transition associated with the start of denitrification in a wastewater treatment processes. J. Appl. Microbiol. 99: 1165-1175.

10. James, B. R. and R. J. Bartl. 1983a. Behaviour of chromium in soils: V Fate of organically complexed $\mathrm{Cr}$ (11I) added to soil. Journal of Environmental Quality 12: 169-172.

11. James, B. R. and R. J. Bartlett. 1983 b. Behaviour of chromium in soils: VI. Interactions between oxidation-reduction and organic complexation. Journal of Environmental Quality 12: 173-176.

12. James, B. R. and R. J. Bartlett. 1983c. Behaviour of chromium in soils: VII. Adsorption and reduction of hexavalent forms. Journal of Environmental Quality 12: 177-181.

13. Naidu, R., et al. 2000. Bioavailability, definition and analytical techniques for assessment and remediation of contaminated (inorganic and organic) soils. Contaminated Site Remediation Conference, From Source Zones to Ecosystems Johnston. 1 (4-8): 283-290.

14. Sharp, M. S. and S. T. Lyles. 1969 Laboratory instruction in biology of microorganisms. Saint Louis the C V Mosley Company, St. Louis. pp. 23-25.

15. Collins, C. H. and P. M. Lyne. 1984. Microbiological Methods, 5th ed. Butterworth and Co. Ltd., London.

16. Claus, G. W. 1995. Understanding Microbes, 4th ed. W.H. Freeman and Co., New York, p. 547.

17. Gerhardt, P. 1913. General Bacteriology. American Society for Microbiologv. 